\title{
URGENSI ETIKA PROFESI PENGEMBANGAN MASYARAKAT ISLAM
}

\author{
Icol Dianto, S.Sos.I., M.Kom.I
}

Fakultas Dakwah dan Ilmu Komunikasi IAIN Padangsidimpuan

icoldianto@gmail.com

\begin{abstract}
Ethics becomes a guiding tool in running a profession. Profession is not only defined as work done with skill or expertise, because in fact the profession includes mastery of theoretical knowledge, theoretical (practical) and experiential implementation. Similarly, the work of the community facilitator profession, which requires an ethical standard to be used as a guide in carrying out its work.Using ethical comparative analysis according to Western and Islamic philosophy, which then attempts to formulate the urgency of the ethical profession of Islamic community facilitator, which includes (a) Guidelines for community facilitator to carry out their duties and responsibilities, (b) the system of norms for professional development and personality, c) benchmark in evaluating the professionalism of community facilitator work.
\end{abstract}

\section{Keywords:}

Urgency, Professional Ethics, Development, Society

\section{A. PENDAHULUAN}

Etika merupakan sikap hidup individu tentang baik dan buruk dalam menjalani kehidupan. Ia tidak berwujud tulisan namun menjadi pegangan bagi manusia untuk bertindak. Ia hadir dalam dimensi abstrak yang mengukur dan menilai perilaku lahiriyah manusia. Ketika ada perbuatan seseorang, maka secara automatic etika memberikan penilaian apakah amaliyah itu baik atau buruk, apakah behavior itu sesuai dengan normanorma atau malahan berbentur dengan kesusilaan yang ada. Etika menyelidi soal-soal, kaidah-kaidah kelakuan serta perbuatan manusia. Etika ialah teori tentang perbuatan manusia ditimbang menurut baik dan buruknya. Alex Sobur ${ }^{1}$ menulis soal etika bahwa etika berbicara tentang kenyataan penghayatan nilai yang pada hakikatnya selalu berhubungan dengan soal keharusan yakni sebuah upaya untuk menemukan dan mencari hal-hal yang baik dan buruk, tindakan yang diperbolehkan atau tidak diperbolehkan.

Durkheim menjelaskan bahwa kondisi masyarakat (social) tanpa dikendalikan oleh etika sosial dapat mendorong terjadinya anomie. Anomi merupakan suatu kondisi dimana

${ }^{1}$ Alex Sobur, Etika Pers Profesionalisme Dengan Nurani, (Bandung, Humaniora Utama Press, 2001), hlm. viii 
perilaku individu tidak terkendali dan tidak terkontrol sebagai akibat dari ketiadaan normanorma dan etika. Kondisi individu pada tingkat ini dikatakan sebagai bentuk bunuh diri (bunuh diri anomik). Durkheim dalam John $\operatorname{Scott}^{2}$ menyebutkan bahwa anomie adalah suatu kondisi tiadanya norma atau tidak adanya aturan-aturan dengan norma-norma bersama. Asumsinya bahwa manusia hanya dapat berisi jika kebutuhan dan nafsu mereka diatur dan dikontrol oleh norma-norma sosial. Jika dibiarkan mereka tidak akan mempunyai standar yang digunakan untuk menilai keberhasilan mereka. Pada tahapan ini, setiap anggota masyarakat perlu dikendalikan oleh suatu nilai, norma dan etika, sehingga kondisi anomie tidak menurut Durkheim itu tidak terjadi dan tidak merusak tatanan sosial. Faisal Badroen $^{3}$ menyebutkan bahwa realitas terkikisnya nilai-nilai luhur dan berkembangnya keinginan untuk dinilai baik secara sosial dapat memupuk jiwa korup dan permisif terhadap ketidakprofesionalan kerja baik di birokrasi, eksekutif, karyawan dan buruh.

Pada kaitannya dengan profesi, etika menjadi alat pandu dalam menjalankan suatu profesi, istilah ini kemudian disebut dengan etika profesi. Profesi tidak hanya diartikan sebagai pekerjaan yang dilakukan dengan keterampilan atau keahlian, karena sesungguhnya profesi itu meliputi pengetahuan teoritik, implementasi teoritik (praktis) dan pengalaman. Profesi hendaknya dapat melingkupi bagaimana penguasaan orang terhadap pengetahuan teoritik, kemampuannya untuk mengimplementasikan teori, dan bagaimana pengalamannya. Kemampuan individu dalam tiga hal itulah yang mengukur keprofesionalan dalam menjalankan profesi tertentu. Misalnya ada seorang pasien penderita jantung, lalu ditangani oleh dokter umum atau spesialis mata, ini jelas tidak etis, dan demikian sebaliknya. Mengapa dikatakan tidak etis, padahal dokter umum itupun mengetahui hal ihwal jantung? Ini adalah alasan profesi dan profesionalisme yang disebutkan di atas; teori, praktik dan pengalaman.

Demikian halnya dalam kerja bidang kemasyarakatan, perlu ada sederetan etika yang harus dianut oleh individu/ kelompok yang menggeluti pekerjaan pendampingan masyarakat. Tenaga pendamping masyarakat bukan alat pemerintah untuk mensukseskan kehendak penguasa. Ia bukan rekanan yang mengejar keuntungan dari proyek-proyek pemerintah. Tenaga pendamping masyarakat harus memihak pada kepentingan masyarakat lapis bawah. Ia merupakan tenaga profesional yang tetap berpegang pada prinsip-prinsip 16

2John Scott, Sosiologi: The Key Conchepts, (Jakarta, PT RajaGrafindo Persada, 2011), hlm.

${ }^{3}$ Faisal Badroen, dkk, Etika Bisnis Dalam Islam, (Jakarta, Kencana, 2015), hlm. 4 
pengembangan masyarakat, selalu berpegang pada prinsip kebutuhan untuk memenuhi kebutuhan masyarakat, prinsip partisipasi yang menekankan pada keterlibatan masyarakat secara aktif, dan prinsip berkelanjutan (sustainable) sampai masyarakat itu mandiri dalam menyelesaikan permasalahannya. Kerja pendampingan masyarakat itu dikatakan sukses bila dikelola dengan tetap memperhatikan prinsip-prinsip di atas. Untuk menjaga agar kegiatan pendampingantetap berjalan pada rel yang benar, maka diperlukan seperangkat alat pengukur etika profesi tersebut.

Perlukah etika profesi pada pekerjaan pendampingan masyarakat? Pertanyaan tersebut mendorong penulis untuk menyelesaikan permasalahan ini dengan menggunakan metode analisis komperatif, yaitu suatu analisis yang membandingkan suatu objek dengan objek lainnya. Dalam hal ini, penulis membandingkan etika menurut filsafat barat dan etika menurut Islam. Dari kajian ini diharapkan munculnya etika profesi pengembangan masyarakat Islam sebagai implementasi nilai-nilai etika keislaman.

\section{B. KAJIAN TEORITIS}

\section{StudiEtika}

Rumusan yang diberikan oleh Departemen Pendidikan dan Kebudayaan ${ }^{4}$ ada dua poin penting tentang etika yaitu etika merupakan asas/ nilai yang berkenaan dengan akhlak, etika merupakan nilai benar-salah yang dianut golongan/ masyarakat, dan etika adalah ilmu tantang apa yang baik dan apa yang buruk, tentang hak dan kewajiban moral. Sebagai pedoman baik buruknya perilaku, etika adalah nilai-nilai, norma-norma dan asasasas moral yang dipakai sebagai pegangan yang umum diterima bagi penentuan baik buruknya perilaku manusia atau benar salahnya tindakan manusia sebagai manusia. ${ }^{5}$ Etika tidak langsung membuat manusia yang lebih baik karena hal itu adalah tugas ajaran moral, melainkan etika merupakan sarana untuk memperoleh orientasi kritis berhadapan dengan pelbagai moralitas yang membingungkan. Meski demikian, etika menjadi penting di tengah masyarakat plural dan modern. Pada masyarakat yang plural sering muncul pandangan terhadap etika yang berbeda dan sebaliknya pada masyarakat yang homogen cenderung berkembang etika yang sama. Pada konteks masyarakat plural, munculnya etika yang beragam disebabkan oleh tiga faktor sebagai berikut:

\footnotetext{
${ }^{4}$ Departemen Pendidikan dan Kebudayaan, Kamus Besar Bahasa Indonesia Edisi II, (Jakarta, Depdikbud, 1995), hlm. 271

${ }^{5}$ Alex Sobur, EtikaPers..., hlm. 5
} 
a. Pandangan-pandangan moral yang berbeda-beda karena orang-orang dari suku, daerah budaya dan agama yang berbeda hidup berdampingan dalam satu masyarakat dan negara.

b. Modernisasi membawa perubahan besar dalam struktur kebutuhan dan nilai masyarakat yang menantang pandangan moral tradisional.

c. Pelbagai ideologi menawarkan diri sebagai penuntun kehidupan, masing-masing dengan ajarannya sendiri tentang bagaimana manusia harus hidup. ${ }^{6}$

Pendapat Franz ini memberikan pemahaman kepada kita bahwa etika yang beragam itu suatu keniscayaan pada masyarakat plural. Pententangan-pertentangan budaya mewarnai pandangan individu/kelompok dalam memandang dunia (fenomena), sehingga baik menurut suatu kelompok masyarakat namun belum tentu baik dalam kacamata masyarakat lainnya. Meskipun pada kenyataan tampak perbedaan, namun etika itu tetap sama pada tujuannya yakni memberikan tuntunan bagi individu/kelompok untuk menilai baik/buruk suatu perbuatan.

\section{Nilai-nilai Etika dalam Islam}

Islam merupakan agama yang sarat nilai. Islam mengatur aspek kehidupan manusia berdasarkan basis moralitas. Nilai-nilai itu merupakan ekspresi imani yang mewujud dalam kepribadian penganutnya. Penghayatannya kepada agama, membentuk seperangkat norma yang dengan itu mereka menilai apakah perbuatan itu baik atau buruk, benar atau salah dalam kacamata agama.

"Diwajibkan atas kamu berperang, padahal berperang itu adalah sesuatu yang kamu benci. Boleh jadi kamu membenci sesuatu, padahal ia amat baik bagimu, dan boleh jadi (pula) kamu menyukai sesuatu, padahal ia amat buruk bagimu. Allah mengetahui, sedang kamu tidak mengetahui".?

Pada konteks ayat tersebut, berperang bagi beberapa orang tidak disenangi karena menjauhkan mereka dengan anak, istri, harta dan kemewahan dunia lainnya. Pandangan itupun masih dianut oleh masyarakat modern yang menginginkan perdamaian dunia, walau terkadang mengorbankan kelompok minoritas dan agama tertentu. Akan tetapi, standar etika dalam perspektif Islam bukan pada akal manusia saja melainkan lebih mengutamakan pada apa yang telah disyariatkan kepada umat Islam melalui rasul-Nya. Seolah-olah Allah itu mengatakan bahwa baik menurut akal manusia belum tentu baik menurut syariat, namun baik menurut syariat itu sudah pasti baik hanya saja akal manusia belum sampai pada pemahaman yang benar atas persoalan itu.

${ }^{6}$ Franz Magis- Suseno, dkk, Etika Sosial, (Jakarta, Gramedia Pustaka Utama, 1991), hlm. 4 ${ }^{7}$ QS. Al-Baqarah (2): 216 
Perkembangan studi etika membedakan etika menjadi dua jenis yaitu etika filosofis yang bersandarkan pada akal budi manusia untuk menilai perbuatan manusia, sementara nilai-nilai etika yang berkaitan dengan nilai-nilai agama, yang dikenal dengan teologi moral/ etika teologis. Etika teologis secara metodis bersumber pada pengalaman iman sebagai tanggapan atas wahyu dalam lembaga agama tertentu. Islam sebagai salah satu agama samawi memiliki nilai-nilai etika universal sesuai dengan keuniversalannya sebagai agama terakhir untuk segenap manusia. Semua nilai-nilai itu terkonsep rapi dalam bentuk kitab suci (al-Quran) dan sunnah Rasulullah. Ada riwayat yang menyebutkan bahwa ketika para sahabat bertanya tentang akhlak Nabi Muhammad Saw, maka Aisyah, istri Nabi, menjawab bahwa akhlak Rasul itu adalah al-Quran. Hal ini memberikan gambaran kepada umat bahwa pembicaraan tentang moral, etika, akhlak dan nilai-nilai sosial dalam perspektif agama Islam, semua itu mesti bersumber pada al-Quran. Nilai-nilai etika dalam Islam adalah sekumpulan nilai yang diatur dalam al-Quran dan sunnah Rasul. Dengan demikian, posisi rasul sebagai tenaga ahli (profesional) dalam mendampingi masyarakat (umat) sudah sepatutnya dijewantahkan dalam bentuk teori pendamping sosial profetik. ${ }^{8}$ Pendapat ini disandarkan atas dasar kesamaan peran yang diemban oleh rasul dengan pendamping sosial. Perbedaan hanya pada siapa donatur atau yang memerintahnya.

Pandangan tentang baik dan buruk ternyata mendapatkan perhatian yang serius oleh para pemikir muslim, ahli kalam dan filosof muslim. Pada banyak literatur tentang baik dan buruk di kalangan ahli ilmu kalam dan filosof muslim, ada dua aliran etika, yaitu kelompok yang berpandangan bahwa akal dapat membedakan baik dan buruk sekalipun belum ada petunjuk wahyu tentang sesuatu itu, kelompok kedua berpandangan bahwa baik dan buruk hanya dapat ditentukan oleh wahyu, sementara kebenaran akal harus dipandu oleh wahyu dan akal tidak dapat membedakan baik dan buruk jika belum ada keterangan yang menjelaskan semua itu.

Kekuatan akal melebihi wahyu tentu tidak dapat diterima begitu saja. Nabi Adam as mengetahui semua nama-nama benda yang ia telah diajari oleh Allah Ta'ala, sementara para malaikat tidak dapat mengetahuinya karena belum diberi petunjuk mengenai namanama benda tersebut. Nabi Adam as belum mengetahui akibat dari melanggar larangan Allah Ta'ala supaya menjauhi pohon khuldi yang dibisikkan oleh syaithan. Padahal pada waktu itu, larangan untuk tidak mendekati pohon itu sudah ada. Alasan-alasan itulah

${ }^{8}$ Icol Dianto, Peranan Dakwah dalam Pengembangan Masyarakat Islam, Jurnal Hikmah, Volume XII, Nomor 1, 2018, hlm. 13 
memberikan pemahaman kepada kita bahwa etika itu tidak hanya sepanjang apa yang dapat diketahui oleh akal melainkan juga aspek-aspek yang diterangkan oleh wahyu. Pemahaman ini tentu saja berbeda dengan ruang lingkup etika yang dikaji dari ilmuan Barat yang berangkat dari filsafat positivisme.

Penulis tidak sepakat dengan Hamzah Ya'qub ${ }^{9}$ yang mengartikan etika adalah ilmu yang menyelidiki mana yang baik dan mana yang buruk dengan memperhatikan amal perbuatan manusia sejauh yang dapat diketahui oleh akal pikiran. Akan tetapi, penulis tidak menyalahkan pendapat yang demikian karena etika itu bersifat relative dan dipengaruhi oleh pendidikan, sosial, budaya, dan agama. Profesor Iwan Triyuwono ${ }^{10}$ yang menyebutkan bahwa etika itu menarik dikaji karena etika memiliki aspek dan landasan berpikir (filsafat) yang beragam, yakni utilitarianism, deontologism, the natural low of ethic, religious ethic, dan theological ethic. Menurut Guru Besar Fakultas Ekonomi Universitas Brawijaya ini, ada dua jenis etika dalam hubungannya dengan agama, yaitu teori keterpisahan dan teori kemanunggalan. Teori keterpisahan berangkat dari filsafat utilitarianism yang beranggapan bahwa sesuatu dipandang etis jika mendatangkan utilitas/ kemanfaatan. Pada tahap selanjutnya, penganut paham ini akan mengabaikan nilai, moralitas agama dan etika dalam upaya mencapai tujuannya, yakni kemanfaatan, inilah yang kemudian disebutnya dengan spiritualitas keterpisahan. Selanjutnya, manusia tidak lepas dari manusia lainnya, alam dan Tuhan. Tiga unsur itu memiliki kesatuan rasa, inilah yang kemudian disebutnya spiritualitas kemanunggalan.

Terlepas dari semua itu, kajian moralitas agama sudah tidak asing lagi dalam ilmu sosiologi, terutama kajian Max Weber, yang kemudian memunculkan kajian The protestant ethic and the spirit capitalism. Muhammad Jakfar ${ }^{11}$ mengutip pendapat Robert N. Bellah yang menyebut bahwa secara teologis maupun sosiologis, agama dapat dipandang sebagai instrument untuk memahami dunia. Kemudian ia mengutip pendapat Bahtiar Effendy, bahwa watak omnipresent agama yaitu agama baik melalui simbolsimbol atau nilai-nilai yang dikandungnya hadir dimana-mana ikut mempengaruhi bahkan membentuk struktur sosial, budaya ekonomi dan politik serta kebijakan publik.

Berdasarkan uraian di atas dapat dipahami bahwa etika dalam Islam merupakan ekspresi umat dalam memahami dan mengamalkan ajaran agama yang bersumberkan pada

\footnotetext{
${ }^{9}$ Hamzah Ya'qub, Etika Islam, (Bandung, Diponegoro, 1988), hlm. 13

${ }^{10}$ Muhammad Jakfar, Anatomi Perilaku Bisnis Dialektika Etika Dengan Realitas, (Malang: UIN Malang Press, 2009), hlm. viii

${ }^{11}$ Muhammad Jakfar, Anatomi Perilaku Bisnis....., hlm. 2
} 
landasan riil dan idil, yakni al-Quran dan sunnah Nabi. Sepatutnyalah nilai-nilai Islam itu tampak pada semua sikap dan perilaku seorang muslim. Inilah yang kemudian dalam kajian etika dikenal dengan theological ethic.

\section{Etika Profesi Pendamping Masyarakat}

Profesi merupakan suatu pekerjaan yang ditekuni yang membutuhkan pengetahuan, keterampilan dan keahlian tertentu. Prayitno dan Erman Amti ${ }^{12}$ mengartikan profesi adalah suatu jabatan atau pekerjaan yang menuntut keahlian dari para petugasnya. Artinya, pekerjaan yang disebut profesi itu tidak bisa dilakukan oleh orang yang tidak terlatih dan tidak disiapkan secara khusus terlebih dahulu untuk melakukan pekerjaan itu. Etika profesi bersinggungan dengan norma-norma sosial/ etika sosial. Etika sosial merupakan normanorma masyarakat yang memberikan petunjuk bagi perilaku seseorang dalam masyarakat. Maclver dan Page seperti dikutip Soerjono Soekanto ${ }^{13}$ menyebutkan bahwa norma pada tingkat pengaturan kebiasaan disebut dengan tata kelakuan (mores). Tata kelakuan mencerminkan sifat-sifat yang hidup dari kelompok manusia yang dilaksanakan sebagai alat pengawas secara sadar maupun tidak sadar oleh masyarakat untuk anggotaanggotanya. Kebiasaan pada tahap ini tidak hanya mencerminkan pada cara berperilaku saja melainkan diterima sebagai norma-norma pengatur perilaku. Menurut Azyumardi Azra dalam Tanggor ${ }^{14}$, menyebutkan etika juga dipandang sebagai karakter atau etos individu/kelompok berdasarkan nilai-nilai dan norma-norma luhur.

Berdasarkan penjelasan pada paragraf sebelumnya, dapat dipahami bahwa etika profesi pendamping masyarakat sangat penting untuk meningkatkan dan mengembangkan keprofesionalan tenaga pendamping masyarakat dalam melaksanakan tugas-tugas pendampingan. Wahyudin Sampeno ${ }^{15}$ menyebutkan, meskipun kedengarannya kode etik profesi dalam bidang ini agak janggal, tetapi kebutuhan pengembangan profesi pendamping masyarakat membutuhkan jaringan dan organisasi yang kuat dengan dukungan aturan profesi termasuk kode etik untuk menjalankan fungsinya. Etika profesi ini bersentuhan dengan etika sosial yang dianut oleh masyarakat, yang menjadi nilai-nilai kearifan lokal. Untuk menghindari benturan antara nilai-nilai yang dipercayai oleh

\footnotetext{
${ }^{12}$ Prayitno dan Erman Amti, Dasar-Dasar Bimbingan dan Konseling, (Penerbit Rineka Cipta), hlm. 338

${ }^{13}$ Soerjono Soekanto, Sosiologi: Suatu Pengantar, (Jakarta, PT RajaGrafindo Persada, 2004), hlm. 201 2014

${ }^{14}$ Tanggor Hasibuan, Etika Publik, Modul Diklat Prajabatan Eselon 1, 2 dan 3 Pola Baru,

${ }^{15}$ Wahyudin Sumpeno, Menjadi Fasilitator Genius, (Yogyakarta, Pustaka Pelajar, 2009), hlm. 23-24
} 
masyarakat lokal dengan kerja pendampingan masyarakat, maka etika profesi ini menjadi sangat urgen dan menjadi sebuah kebutuhan pada standar etika untuk menjalankan profesi pendampingan masyarakat.

Kode etik tidak akan membatasi kerja fasilitator, tetapi sebagai cara untuk mengembangkan kemampuan kerja dan pelayanan terhadap masyarakat. Kode etik merupakan seperangkat tata nilai atau norma yang disepakati dan diakui oleh suatu organisasi dan harus dipelihara oleh fasilitator dalam melaksanakan tugas secara profesional. Nilai-nilai tersebut merupakan bagian dari wujud profesionalisme yang harus ditaati oleh fasilitator. Kode etik berisi hal-hal yang harus dilaskanakan dan harus dihindari oleh fasilitator. Dengan demikian, kode etik profesional (professional code ethic) merupakan suatu sistem peraturan, tata nilai atau seperangkat prinsip perilaku yang telah diterima oleh individu atau kelompok yang bergabung dalam himpunan organisasi profesi.

Dalam menjalankan tugas pendampingan masyarakat, seorang fasilitator tidak hanya menunjukkan kinerjanya atau kecakapan untuk mengerjakan suatu pekerjaan, tetapi sekaligus menjaga dan memelihara perilaku serta sikap yang dapat dipertanggungjawabkan. Kode etik menjadi panduan normatif fasilitator dalam mengembangkan tugas profesi. Landasan normatif ini dipandang sebagai cara untuk melindungi integritas fasilitator serta memberi peluang terhadap tuntutan hukum pihak lain bila terjadi pelanggaran yang merugikan masyarakat.

Asosiasi Konsultan Pendampingan Pembangunan Indonesia (AKPPI) merumuskan kode etik dan tata laku konsultan pembangunan sebagai berikut:

1. Konsultan pembangunan berpihak pada masyarakat

2. Konsultan pembangunan berorientasi pada kemandirian masyarakat

3. Konsultan pembangunan menjalankan fungsinya sebagai fasilitator atau pendamping kelompok masyarakat.

4. Konsultan pembangunan merangkai berbagai pihak ke dalam iklim kemitraan.

5. Konsultan pembangunan mengupayakan pemberdayaan masyarakat miskin.

6. Konsultan pembangunan bersifat proaktif dan memiliki komitmen secara berkesinambungan.

7. Konsultan pembangunan lebih berorientasi pada proses pemberdayaan daripada target fisik semata.

8. Konsultan pembangunan mengupayakan penyelesaian konflik, mengatasi masalah kelompok masyarakat melalui komunikasi dan keterbukaan.

9. Konsultan pembangunan menerapkan pendekatan pembangunan bertumpu pada masyarakat yang berdasarkan keadilan dan pemerataan.

10. Konsultan pembangunan menganut dan menjunjung tinggi integritas profesi, demokrasi, kemandirian, keterbukaan dan pembangunan berkelanjutan. ${ }^{16}$

\footnotetext{
${ }^{16}$ Wahyudin Sumpeno, Menjadi Fasilitator Genius..., hlm. 35
} 
Etika profesi konsultan pembangunan yang dikemukakan oleh AKPPI di atas merupakan rumusan yang dikemukakan oleh organisasi profesi, yang tentu saja dipatuhi oleh internal organisasi dan belum tentu diimplementasikan oleh organisasi lainnya dalam profesi yang sama. Oleh karena itu, perlu rumusan-rumusan lain sebagai alternatif bagi individu/lembaga yang bergumul pada profesi pendamping sosial. Etika sebenarnya tidak lepas dari prinsip-prinsip yang dipatuhi oleh suatu profesi. Berangkat dari prinsip-prinsip dakwah pengembangan masyarakat yang dikemukakan oleh Icol Dianto ${ }^{17}$ ada enam prinsip-prinsip dakwah pengembangan masyarakat; prinsip kebutuhan, prinsip partisipasi, prinsip keterpaduan, prinsip berkelanjutan, prinsip keserasian, prinsip kemampuan sendiri.

1. Tenaga pendamping masyarakat berpegang teguh pada agama dan kepercayaan kepada Tuhan YME.

2. Pendamping masyarakat mengutamakan kebutuhan masyarakat lapis bawah.

3. Pendamping masyarakat memberikan kesempatan seluas-luasnya kepada warga untuk aktif terlibat pada kegiatan pemerintahan dan non pemerintahan.

4. Pendamping masyarakat menggerakan masyarakat untuk memanfaatkan semua potensi sumber daya alam dan manusia demi meningkatkan taraf hidup masyarakat lapis bawah.

5. Pendamping masyarakat mengutamakan kegiatan pengembangan yang berkelanjutan dengan memperhatikan ketersediaan sumberdaya dan kerusakan lingkungan.

6. Tenaga pendamping masyarakat mempertimbangkan keserasian kebutuhan dan hubungan warga dengan pihak lain.

7. Pendamping masyarakat berorientasi pada upaya mewujudkan kemandirian warga untuk menyelesaikan persoalan kehidupan mereka sendiri.

Rumusan etika di atas tentu saja dapat diubah dan berbeda antara satu organisasi dengan organisasi lain, karena dalam ilmu sosial itu tidak ada suatu fenomena yang statis melainkan selalu berubah pada tempat dan waktu yang berbeda.

\section{URGENSI ETIKA PROFESI PENDAMPING MASYARAKAT}

Kerja pendampingan masyarakat berupaya mentransformasi inovasi-inovasi teknologi kepada masyarakat. Teknologi yang berkembang sedemikian pesat perlu dilakukan penyaringan (filterisasi) oleh nilai-nilai atau moral. Apalagi teknologi dijadikan

${ }^{17}$ Icol Dianto, DIKTAT: Dasar-Dasar Pengembangan Masyarakat Islam, (Padangsidimpuan: FDIK Press, 2016), hlm. 21-22 
alat untuk mendukung kerja suatu profesi. M. Munandar Soelaeman ${ }^{18}$ menulis bahwa kebudayaan dan nilai-nilai yang dulu dijunjung tinggi sedikit demi sedikit luntur akibat berkembangnya ilmu dan teknologi. Kearifan masyarakat tradisional dalam menjaga keseimbangan dengan lingkungan alam dirusak oleh kebijaksanaan eksploitasi yang dimotivasi oleh ilmu dan kecanggihan teknologi. Di sinilah mengapa etika profesi pendamping masyarakat menjadi penting untuk dirumuskan. Kerja pendampingan tidak dinilai pada perspektif fisik atau keberhasilan pembangunan yang bersifat top-down dan mengabaikan kepentingan dan keterlibatan masyarakat lokal.

Berdasarkan penjelasan sebelumnya, maka urgensi etika profesi pengembangan masyarakat Islam dapat dirumuskan sebagai berikut:

\section{Pedoman bagi pendamping sosial masyarakat untuk melaksanakan tugas dan tanggungjawabnya.}

Kerja pendampingan masyarakat memiliki kepentingan yang berpihak pada masyarakat lapis bawah. Pendamping masyarakat berani pasang badan untuk melawan rezim dan menentang kebijakan yang merugikan kliennya. Akan tetapi, di sisi lain ada dilema yang tidak bisa diabaikan pengaruhnya begitu saja. Tenaga pendamping masyarakat tidak muncul begitu saja sebagai manusia penyelamat umat. Ia ada karena ada pihak lain yang memberikan tugas dan tanggungjawab. Dalam hal ini, pendamping masyarakat terikat kontrak kerja dengan pihak pendonor, apakah ia sebagai pendamping masyarakat yang diberi imbalan (upah/gaji) oleh pemerintah maupun sebagai pendamping masyarakat dari komunitas, lembaga swadaya masyarakat, dan lembaga independen lainnya.

Keterikatan kerja pendamping masyarakat dengan pendonor, dapat mempengaruhi kerja profesionalnya sebagai pembela kepentingan rakyat lapis bawah. Pemerintah sebagai pendonor, memiliki target-target kerja yang harus dicapai. Dalam mencapai target itu, seringkali prinsip-prinsip kerja pendampingan masyarakat diabaikan. Pemanfaatan potensi sumberdaya lokal dan keberdayaan masyarakat terkadang dipaksa harus sesuai dengan keinginan (target) pihak pendonor. Begitu juga pendonor dari pihak swasta yang menginginkan pendamping masyarakat itu melaksanakan program-program yang mendukung visi dan misi lembaga pendonor.

${ }^{18}$ M. Munandar Soelaeman, IImu Sosial Dasar: Teori dan Konsep IImu Sosial, (Bandung, Eresco, 1989), hlm. 173. 
Tenaga pendamping masyarakat yang profesional, tidak mengedepankan sebesar apa imbalan yang akan diterima atau berapa bantuan pendonor yang dapat diraup, karena kehadirannya di tengah-tengah masyarakat, tidak untuk mendapatkan keuntungan (profit) bagi diri dan lembaganya, melainkan kehadirannya untuk membantu masyarakat untuk mendapatkan hak-hak mereka. Oleh karena itu, selama menjalankan profesinya ia mesti berpedoman pada tugas dan tanggungjawabnya sebagai tenaga pendamping masyarakat bukan sebatas pada peran sebagai pekerja yang dibayar pemerintah/ swasta.

\section{Sistem norma untuk pengembangan profesi dan kepribadian}

Pada dasarnya tidak ada yang sempurna di jagad raya ini melainkan hanya Allah saja. Kekurangan satu individu/kelompok dapat ditutupi oleh kelebihan yang dimiliki oleh individu/kelompok lainnya. Oleh karena itu, kebutuhan antar makhluk itu muncul sebagai suatu bentuk keserasian dengan fitrahnya yang tidak sempurna dan berkekurangan. Demikian juga dengan profesi pengembangan masyarakat yang tentu saja masih ada peluang untuk terus dikembangkan menuju ke arah yang lebih baik.

Etika yang telah dibakukan dalam bentuk kode etik profesi membentuk seperangkat nilai (sistem norma) yang mesti ditaati dan dipatuhi. Penjelasan menarik dari Wahyudin Sumpeno yang menyebutkan bahwa kode etik tidak akan membatasi kerja fasilitator, tetapi sebagai cara untuk mengembangkan kemampuan kerja dan pelayanan terhadap masyarakat. Kode etik merupakan seperangkat tata nilai atau norma yang disepakati dan diakui oleh suatu organisasi dan harus dipelihara oleh fasilitator dalam melaksanakan tugas secara profesional. Tentu saja kondisi kejiwaan yang demikian hebat, sami'na wa 'atha'na, tidak muncul begitu saja. Telah terjadi proses internalisasi nilai-nilai, sehingga pada diri pendamping sosial muncul kematangan bertindak. Inilah maksud penulis, salah satu urgensi etika profesi itu menjadi suatu sistem norma untuk pengembangan profesi dan kepribadian.

\section{Tolok ukur dalam mengevaluasi profesionalitas kinerja pendamping masyarakat.}

Apa yang menjadi tolok ukur keprofesionalan bagi seseorang yang menggeluti suatu pekerjaan. Jawabnya tentu saja adalah mereka yang menjalankan profesi sesuai dengan standar operasional prosedur. Dalam standar operasional prosedur itu telah terwakili nilainilai ethic dalam menjalankan suatu profesi. Dengan kata lain, seorang yang melanggar standar operasional prosedur dapat juga dinilai telah melanggar suatu etika. Menurut pemahaman ini, etika dapat dijadikan sebagai tolok ukur untuk menilai tindakan seseorang, apakah etis atau tidak etis. 
Ada sementara orang beranggapan bahwa job and descriptions sebagai tolok ukur untuk menilai profesionalisme seseorang yang menggeluti profesi tertentu. Orang yang menjalankan job and descriptions dengan baik maka ia dikatakan berhasil atau profesional. Anggapan ini tentu saja tidak salah, namun mengklaim satu-satunya faktor penentu keprofesionalan suatu profesi adalah job and descriptions tidak dapat diterima begitu saja. Pada job and descriptions tentu ada nilai yang tersirat, yang bila dilanggar oleh pemilik profesi, akan berdampak pada penilaian kepribadian. Ini juga berkaitan dengan etika. Oleh karena itu, penulis memasukan pernyataan bahwa urgensi etika profesi sebagai tolok ukur dalam mengevaluasi profesionalisme kinerja pendamping masyarakat.

\section{PENUTUP}

Etika merupakan sikap hidup individu tentang baik dan buruk dalam menjalani kehidupan. Pada kaitannya dengan profesi, etika menjadi alat pandu dalam menjalankan suatu profesi. Pada kajian ini, penulis menemukan ada tiga urgensi etika pendamping sosial yakni (1) Pedoman bagi pendamping sosial masyarakat untuk melaksanakan tugas dan tanggungjawabnya, (2)Sistem norma untuk pengembangan profesi dan kepribadian, dan (3) Tolok ukur dalam mengevaluasi profesionalisme kinerja pendamping masyarakat.

\section{E. DAFTAR KEPUSTAKAAN}

Alex Sobur, Etika Pers Profesionalisme Dengan Nurani, Bandung: Humaniora Utama Press, 2001.

Departemen Pendidikan dan Kebudayaan, Kamus Besar Bahasa Indonesia Edisi II, Jakarta: Depdikbud, 1995.

Faisal Badroen, dkk, Etika Bisnis Dalam Islam, Jakarta: Kencana, 2015.

Franz Magis- Suseno, dkk, Etika Sosial, Jakarta: Gramedia Pustaka Utama, 1991.

HamzahYa'qub, Etika Islam, Bandung: Diponegoro, 1988.

Icol Dianto, Peranan Dakwah Dalam Pengembangan Masyarakat Islam, Jurnal Hikmah, Volume XII, Nomor 1, 2018.

John Scott, Sosiologi: The Key Conchepts, Jakarta: PT RajaGrafindo Persada, 2011.

Muhammad Jakfar, Anatomi Perilaku Bisnis Dialektika Etika Dengan Realitas, Malang: UIN Malang Press, 2009.

M. Munandar Soelaeman, Ilmu Sosial Dasar: Teori dan Konsep Ilmu Sosial, Bandung: Eresco, 1989.

Prayitno dan Erman Amti, Dasar-Dasar Bimbingan dan Konseling, Penerbit Rineka Cipta. Soerjono Soekanto, Sosiologi: Suatu Pengantar, Jakarta: PT RajaGrafindo Persada, 2004. Tanggor Hasibuan, Etika Publik,Modul Diklat Prajabatan Eselon 1, 2 dan 3 Pola Baru, 2014.

Wahyudin Sumpeno, Menjadi Fasilitator Genius, Yogyakarta: Pustaka Pelajar, 2009. 